\title{
Transmission efficiency of Grapevine leafroll-associated virus 3 (GLRaV-3) by the mealybugs Planococcus ficus and Pseudococcus longispinus (Hemiptera: Pseudococcidae)
}

\author{
N. Douglas ${ }^{1}$ and K. Krüger ${ }^{1}$
}

(1) Department of Zoology and Entomology, University of Pretoria, Pretoria, 0002, South Africa

K. Krüger

Email: kkruger@zoology.up.ac.za

\section{Abstract}

Grapevine leafroll-associated virus 3 (GLRaV-3) is transmitted from grapevine to grapevine through grafting infected material, as well as mealybug and soft scale insect vectors. We determined the transmission efficiency of GLRaV-3 by two mealybug vectors, Planococcus ficus and Pseudococcus longispinus, by examining the relationship between the number of nymphs per plant, using groups of 1, 5, 10, 20 and 40 first- to second-instar nymphs, and the infection rate of healthy grapevine plants. Plants and single nymphs were tested for GLRaV-3 with nested reverse transcription polymerase chain reaction (nested RT-PCR). The results of this study showed the infection rate of $P$. ficus and $P$. longispinus nymphs with GLRaV-3 after acquisition access and inoculation access periods of 5 days each to be similar between intra- and interspecific groups, ranging from $5 \%$ to $19 \%$, except for the '40-nymph group' of $P$. longispinus, which had a higher number of infected nymphs (63\%). The number of nymphs used per group did not influence the infection rate of plants, which ranged from $11 \%$ to $80 \%$ and $20 \%$ to $70 \%$ for $P$. ficus and $P$. longispinus, respectively. Transmission of GLRaV-3 with single $P$. ficus and $P$. longispinus nymphs resulted in 70\% GLRaV-3 positive plants in both cases. This study has shown both species to be equally efficient as vectors of GLRaV-3. We have further shown for the first time that a single individual of either $P$. ficus or $P$. longispinus is capable of transmitting GLRaV-3 and infecting a healthy grapevine plant. The results of the study highlight the importance of implementing vector control measures. 


\section{Introduction}

Grapevine leafroll disease (GLD) is one of the most serious viral diseases of grapevine, occurring in all grapevine-growing areas worldwide (Martelli 1986). The disease causes qualitative and quantitative losses to yield (Goheen and Cook 1959; Credi and Babini 1997; Cabaleiro et al. 1999). In addition, it has a rapid spread rate, infecting a new vineyard within only a few years (Krake et al. 1999). The disease is associated with a group of at least nine closely related viruses belonging to the family Closteroviridae (Martelli et al. 2002; Alkowni et al. 2004). Grapevine leafroll-associated virus 3 (GLRaV-3), the type member of the genus Ampelovirus, is one of the most abundant of the leafroll-associated viruses (Martin et al. 2005; Pietersen 2006; Akbas et al. 2007). Grapevine leafroll disease is transmitted through grafting infected material and mealybug (Pseudococcidae) and soft scale insect (Coccidae) vectors (Tanne et al. 1989; Engelbrecht and Kasdorf 1990; Belli et al. 1994; Cabaleiro and Segura 1997; Petersen and Charles 1997; Golino et al. 2002; Sforza et al. 2003). GLRaV-3 is thought to be transmitted in a semi-persistent manner by its insect vectors (Martelli et al. 2002), although a recent study suggests a circulative transmission mechanism (Cid et al. 2007). Two known mealybug vectors are the vine mealybug Planococcus ficus and the longtailed mealybug Pseudococcus longispinus (Engelbrecht and Kasdorf 1990; Petersen and Charles 1997). These species have been reported from many grapevine-growing regions, including Europe, North and South America, and Africa.

Due to its high abundance in vineyards, $P$. ficus is considered the most important vector of GLRaV-3 in South Africa. Pseudococcus longispinus is far less abundant on grapevine and has a more aggregated distribution in vineyards than $P$. ficus in this country (Walton and Pringle 2004). The difference in abundance on grapevine between the two species suggests that $P$. ficus may be a more efficient vector of GLRaV-3 than P. longispinus. Very little work has been done on plant virus transmission efficiency by mealybugs using different numbers of vectors. Studies which examined the relationship between the number of individual mealybugs and virus-infected plants include those on the grey pineapple mealybug Dysmicoccus neobrevipes (Hemiptera: Pseudococcidae) transmitting the Pineapple mealybug wilt-associated virus (PMWaV, Closteroviridae) and on Planococcoides njalensis (Hemiptera: Pseudococcidae) transmitting Cocoa swollen shoot virus (CSSV, Caulimoviridae; Roivainen 1976; Sether et al. 1998). In general, the number of infected plants increased with rising mealybug numbers in these studies. However, no study has thus far compared the transmission efficiency of GLRaV-3 using different numbers of mealybugs.

The objective of this study was to examine the relationship between the number of firstto second-instar nymphs per plant of $P$. ficus and $P$. longispinus and the infection rate of healthy grapevine plants to determine GLRaV-3 transmission efficiency. 


\title{
Materials and methods
}

\author{
Insects \\ A non-viruliferous culture of $P$. ficus, with specimens obtained from the Western Cape \\ (South Africa), established on butternut (Cucurbita moschata (Cucurbitaceae)) together \\ with a non-viruliferous culture of $P$. longispinus established on Alocasia macrorrhizos \\ (Araceae) were used. Both species were maintained at $25^{\circ} \mathrm{C}, 16: 8 \mathrm{~L}: \mathrm{D}$ and natural \\ humidity. Both butternut and A. macrorrhizos are non-hosts of GLRaV-3. The \\ identification of both mealybug species was done using the multiplex PCR described by \\ Saccaggi et al. (2008) and confirmed by Ian Millar of the Biosystematics Division of the \\ ARC - Plant Protection Research Institute (ARC-PPRI). Sub-samples of $P$. ficus and $P$. \\ longispinus nymphs collected from the cultures that served as negative controls were \\ tested for GLRaV-3 before any transmission experiments by nested reverse transcription \\ polymerase chain reaction (nested RT-PCR) to confirm their virus-free status. First- to \\ second-instar nymphs were used for transmission experiments.
}

\section{Plants}

Virus-free grapevines (Vitis vinifera (Vitaceae), cv. Cabernet franc) propagated at Kaapse Wyn Vereniging (KWV) in Paarl (Western Cape, South Africa) served as indicator vines for the experiments. Each of the 104 Cabernet franc indicator plants was tested for GLRaV-3 three times at 2-month intervals between each test to confirm their virus-free status with nested RT-PCR. Four plants propagated from stem cuttings of the rootstock hybrid LN33 (1/5/2, ARC Infruitec-Nietvoorbij, South Africa) infected with GLRaV-3 served as virus source. LN33 plants were tested before experiments to confirm their virus status.

\section{Transmission of GLRaV-3}

To determine the transmission efficiency between the number of nymphs per plant of both $P$. ficus and $P$. longispinus, nymphs of each species were transferred from their respective cultures to virus source plants (LN33) for acquisition access periods (AAPs) of 5 days. Care was taken to select symptomatic leaves, i.e. leaves exhibiting red interneural discoloration, green veins and downward-rolled leaf margins. In addition, petioles of leaves used for virus acquisition were tested with nested RT-PCR after AAPs to confirm their virus status. Small leaf cuttings of the virus-source plants containing groups of 1, 5, 10, 20 and 40 nymphs of each mealybug species, respectively, were transferred to separate indicator plants for inoculation access periods (IAPs) of 5 days. Ten indicator plants per species and group were used. The number of plants per treatment was limited by the number of virus-, insect- and pesticide-free grapevine plants available. For each respective mealybug species, each experimental group was placed in a separate cage to avoid cross-contamination by movement of mealybugs between plants. As this may also occur between cages, each cage was placed on four saucers containing engine oil to avoid movements of mealybugs between cages.

The nymphs moved from the cuttings to plants within $24 \mathrm{~h}$ as the small leaf-cuttings desiccated. After completion of the IAP, plants were treated with two insecticides, chlorpyrifos and imidacloprid, to remove any remaining mealybugs and to prevent re- 
infestation. Thereafter plants were transferred to a plant growth room. Three plants each exposed to 15 GLRaV-3- free mealybug nymphs of $P$. ficus and $P$. longispinus for feeding periods of 5 days served as negative controls. Transmission experiments were carried out and plants maintained at $25^{\circ} \mathrm{C}, 16: 8 \mathrm{~L}: \mathrm{D}$ and natural humidity.

After AAPs of 5 days on virus source plants and IAPs of 5 days on virus indicator plants, sub-samples of the mealybugs were removed and tested for the presence of GLRaV-3. Indicator plants were tested for GLRaV-3 starting 8 weeks after transmission and then in intervals for up to 11 months.

\section{Virus isolation and RT-PCR}

The method described by La Notte et al. (1997) was used for GLRaV-3 extraction. Plant sap from single petioles was spotted and single mealybug nymphs were crushed on a positively charged nylon membrane (Roche Diagnostics, Mannheim, Germany) soaked in a $50 \mathrm{mM} \mathrm{NaOH}$ and $2.5 \mathrm{mM}$ EDTA solution, then allowed to dry at room temperature for at least $1 \mathrm{~h}$. A $4 \mathrm{~mm}^{2}$ piece of the spotted membrane was cut out and placed in $30 \mu \mathrm{l} 1 \times$ GES buffer (La Notte et al. 1997). The sample was then incubated at $95^{\circ} \mathrm{C}$ for $10 \mathrm{~min}$ and cooled on ice before being used for PCR.

The external and internal primer sets designed by Ling et al. (2001) were used for GLRaV-3 detection. PCR was performed following the protocol adapted from Ling et al. (2001) by M. van der Merwe (ARC-PPRI, South Africa). The $50 \mu 1$ reaction volume contained $2.5 \mu \mathrm{l} 2 \%$ Triton-X, $\mathrm{NH}_{4}$ buffer (final concentration: $16 \mathrm{mM}(\mathrm{NH} 4)_{2} \mathrm{SO}_{4}$, $67 \mathrm{mM}$ Tris-HCl, $0.01 \%$ Tween-20), $1.5 \mathrm{mM} \mathrm{MgCl}_{2}, 10 \mathrm{mM}$ DTT, $0.5 \mu \mathrm{M}$ of each external primer, $175 \mu \mathrm{M}$ of each dNTP, $18 \mu \mathrm{M}$ HPRI RNase inhibitor, $40 \mu \mathrm{M}$ M-MLV reverse transcriptase, and $0.5 \mu \mathrm{M}$ BIOTAQ ${ }^{\mathrm{TM}}$ DNA Polymerase (BioLine, Luckenwalde, Germany) and $3 \mu \mathrm{l}$ of the extraction. PCR thermal cycling conditions for the first-round PCR were: $37^{\circ} \mathrm{C}$ for $45 \mathrm{~min}, 94^{\circ} \mathrm{C}$ for $2 \mathrm{~min}$, then 35 cycles at $94{ }^{\circ} \mathrm{C}$ for $60 \mathrm{~s}, 50^{\circ} \mathrm{C}$ for $60 \mathrm{~s}, 72^{\circ} \mathrm{C}$ for $2 \mathrm{~min}$, and a final extension at $72{ }^{\circ} \mathrm{C}$ for $10 \mathrm{~min}$. Second-round amplification was carried out with $0.5 \mu$ of the first-round product added to $50 \mu 1$ of reaction mixture prepared as described above using the internal primer set and omitting DTT, RNase inhibitor, and reverse transcriptase. The cycling programme conditions were: $94{ }^{\circ} \mathrm{C}$ for $2 \mathrm{~min}$, then 33 cycles at $94{ }^{\circ} \mathrm{C}$ for $60 \mathrm{~s}, 50{ }^{\circ} \mathrm{C}$ for $60 \mathrm{~s}$ and $72{ }^{\circ} \mathrm{C}$ for $2 \mathrm{~min}$, and a final extension at $72{ }^{\circ} \mathrm{C}$ for $10 \mathrm{~min}$. PCRs were performed using GenAmp PCR System 2400 (Perkin Elmer Applied Biosystems) and 2720 Thermal Cycler (Applied Biosystems) thermocyclers. PCR products were visualized under UV light on a $1.5 \%$ agarose gel stained with ethidium bromide $(\mathrm{EtBr})$.

\section{Statistical analysis}

Chi-square $\left(\chi^{2}\right)$ tests were used to determine differences between groups of nymphs within and between species. The Bonferroni adjustment was used when performing multiple statistical significance tests on the same data (Sokal and Rohlf 1995). All analyses were carried out on a Microsoft ${ }^{\circ}$ Office Excel 2003 spreadsheet. None of the $P$. longispinus nymphs of the '1-nymph group' tested positive for GLRaV-3. This and groups where only one plant or nymph tested positive for GLRaV-3 were excluded from the statistical analyses. 


\section{Results and discussion}

Leafroll viruses are rather unevenly distributed in grapevine plants (La Notte et al. 1997). This is reflected in some mealybugs testing negative for GLRaV-3 after AAPs of 5 days on GLRaV-3 positive leaves, suggesting that mealybugs feeding on different parts of a leaf were exposed to different virus loads, thus having a different probability of acquiring the virus. Only $17 \%$ percent of the $P$. ficus and $29 \%$ of the P. longispinus nymphs tested positive for GLRaV-3 in the control groups (Table 1).

Table 1 Infection of single first- to second-instar nymphs of Planococcus ficus and Pseudococcus longispinus with GLRaV-3 after acquisition access and inoculation access periods of 5 days each on infected and virus-free grapevine plants, respectively

\begin{tabular}{|l|l|l|}
\hline \multirow{2}{*}{$\begin{array}{l}\text { No. of nymphs } \\
\text { per plant }\end{array}$} & $\begin{array}{l}\text { P. ficus } \\
\text { No. GLRaV-3 positive } \\
\text { nymphs/no. of nymphs tested (\%) } \\
\text { infected) }\end{array}$ & $\begin{array}{l}\text { No. GLRaV-3 positive } \\
\text { nymphs/no. of nymphs tested (\% } \\
\text { infected) }\end{array}$ \\
\hline 1 & $1 / 7(14.3)$ & $0 / 9(0)$ \\
\hline 5 & $5 / 31(16.1)$ & $4 / 30(13.3)$ \\
\hline 10 & $2 / 15(13.3)$ & $3 / 21(14.3)$ \\
\hline 20 & $2 / 38(5.3)$ & $5 / 26(19.2)$ \\
\hline 40 & $2 / 25(8.0)$ & $19 / 30(63.3)$ \\
\hline Positive control & $5 / 29(17.2)$ & $7 / 24(29.2)$ \\
\hline $\begin{array}{l}\text { Negative } \\
\text { control }\end{array}$ & $0 / 20(0)$ & $0 / 20(0)$ \\
\hline
\end{tabular}

Nymphs collected from GLRaV-3 infected grapevine plants after a 5-day AAP and butternut served as positive and negative controls, respectively.

When excluding the '40-nymph' $P$. longispinus group, the mean number of GLRaV-3 positive nymphs of $P$. ficus $(10 \%)$ and $P$. longispinus (14\%) after IAPs of 5 days was $7 \%$ and $15 \%$ lower than the respective control groups after a 5-day AAP (Table 1). Infection of $P$. ficus nymphs with GLRaV-3 was similar for all groups, ranging between $5 \%$ and $16 \%\left(\chi^{2}=2.516 ; d f=3 ; P>0.05\right)$. GLRaV-3 infection of $P$. longispinus nymphs of the ' $40-$ nymph group' at $63 \%$ was significantly higher compared to 13 to $19 \%$ in the 5-, 10 - and 20 -nymph groups $\left(\chi^{2}=24.19, d f=3, P<0.001\right)$. Comparing the two species, the number of $P$. ficus and $P$. longispinus GLRaV-3 infected nymphs was similar except for the ' 40 nymph group' $\left(\chi^{2}=9.525, d f=1, P<0.05\right)$. The results indicate that any difference between infection rates of plants would be due to differences in the number of nymphs used for GLRaV-3 transmission except for the '1-nymph' and '40-nymph' groups of $P$. longispinus. 
Studies by Roivainen (1976) and Sether et al. (1998) showed that numbers of virus positive plants and mealybugs used for virus transmission were correlated. Exposure of plants to groups of 10, 20 and 40 viruliferous $D$. neobrevipes nymphs resulted in significantly more PMNaV infected plants than exposure to either single or groups of five viruliferous nymphs (Sether et al. 1998). Roivainen (1976), examining the transmission characteristics of CSSV by $P$. njalensis, demonstrated a positive linear relationship between the number of nymphs per plant used for transmissions and the number of infected plants. No such relationship was observed in the present study. GLRaV-3 infection rates of grapevine plants ranged between $30 \%$ to $80 \%$ and $20 \%$ to $70 \%$ for $P$. ficus and $P$. longispinus groups, respectively, with the exception of the ' 10 -nymph' $P$. ficus group, where only one plant tested positive. In contrast to Roivainen (1976) and Sether et al. (1998) more plants were infected using single or groups of five nymphs than groups of 10, 20 and 40 nymphs. However, differences between groups were not significant $\left(P\right.$. ficus: $\chi^{2}=5.84, d f=3, P>0.05, P$. longispinus: $\chi^{2}=4.80, d f=3, P>0.05$, Table 2).

Table 2 Infection of grapevine (Cabernet franc) plants with GLRaV-3 using different numbers of Planococcus ficus and Pseudococcus longispinus first- to second-instar nymphs

\begin{tabular}{|l|l|l|}
\hline $\begin{array}{l}\text { No. of nymphs } \\
\text { per plant }\end{array}$ & $\begin{array}{l}\text { P. ficus } \\
\text { No. GLRaV-3 positive plants/no. } \\
\text { of plants tested (\% infected) }\end{array}$ & $\begin{array}{l}\text { No. GLRaV-3 positive plants/no. } \\
\text { of plants tested (\% infected) }\end{array}$ \\
\hline 1 & $7 / 10(70.0)$ & $7 / 10(70.0)$ \\
\hline 5 & $8 / 10(80.0)$ & $4 / 10(40.0)$ \\
\hline 10 & $1 / 9(11.1)$ & $5 / 9(55.6)$ \\
\hline 20 & $3 / 10(30.0)$ & $2 / 9(22.2)$ \\
\hline 40 & $5 / 9(55.6)$ & $1 / 5(20.0)$ \\
\hline $\begin{array}{l}\text { Negative } \\
\text { control }\end{array}$ & $0 / 3(0)$ & $0 / 3(0)$ \\
\hline
\end{tabular}

Groups of 15 virus-free nymphs were transferred to virus-free grapevine plants to serve as negative controls.

There was a discrepancy between the percentage of nymphs infected within a group and the infection rate of the corresponding plant groups. For example, even though none of the $P$. longispinus nymphs of the '1-nymph group' tested positive for GLRaV-3 after 5day AAPs and 5-day IAPs, $70 \%$ of the grapevine plants in this group tested positive. In addition, significantly more nymphs tested positive for GLRaV-3 in the '40-nymph group,' whereas the number of positive plants at $20 \%$ was the lowest of all groups for $P$. longispinus. However, when excluding the '40-nymph' $P$. longispinus group, the number of positive nymphs of $P$. ficus and $P$. longispinus was lower after AAPs and IAPs of 5 days each than the respective controls after 5-day AAPs only (Table 1). These differences could possibly be due to nymphs having moulted during the 10-day period 
(5 days AAP and 5 days IAP), loss of infectivity, and/or the sensitivity and detection levels of the PCR being insufficient to detect GLRaV-3. A further possibility would be contamination. However, various controls were included in the study to test for contamination and precautions were taken to avoid cross-contamination between cages. Further, none of the negative controls tested positive.

Transmission efficiency of $P$. ficus varies between studies. For example, a study carried out under similar experimental conditions, with exception of AAPs ranging from 1 to 7 days, found that more than $60 \%$ of the grapevines were infected with GLRaV-3 when exposed to viruliferous $P$. ficus using 15-20 nymphs per plant (Krüger et al. 2006). In the current study $30 \%$ of plants tested positive for GLRaV-3 using 20 nymphs. Related work carried out with $P$. longispinus under the same experimental conditions as in the current study, with exception of an AAP of 1 day and using 20 P. longispinus nymphs per plant, resulted in $40 \%$ of grapevines being infected with GLRaV-3 (Krüger et al. 2006). In addition, Petersen and Charles (1997), using 10 P. longispinus nymphs per plant, found that after an AAP of 7 days with ten nymphs per plant $57 \%$ of grapevine plants tested positive for GLRaV-3. The current study found $22 \%$ of grapevines to be infected with GLRaV-3. These differences in transmission by P. ficus and P. longispinus observed in the current study compared to previous investigations could be due to differences in experimental design and/or variation between experiments. A similar observation was also made by Roivainen (1976) in experiments on transmission of cocoa viruses by $P$. njalensis.

The lower abundance of $P$. longispinus compared to P. ficus on grapevine in South Africa indicates that this species is not as well adapted to grapevine as a host plant as the latter, suggesting that it is a less efficient vector of GLRaV-3. However, there was no difference in the number of plants infected with GLRaV-3, using the same number of nymphs, between the $P$. ficus and $P$. longispinus groups in the current study $\left(\chi^{2}=0.007-2.81, d f=1\right.$, $P>0.05$ ). This demonstrates that $P$. longispinus is as efficient a vector as $P$. ficus.

In addition, the present study has shown for the first time that a single nymph of either $P$. ficus or $P$. longispinus is capable of infecting a healthy grapevine plant with GLRaV-3. In both instances the transmission efficiency of the virus, at $70 \%$, was high. This emphasizes the importance of sanitary measures in vineyards to reduce virus spread, which may occur through labourers and equipment such as pliers and harvesting machines infested with mealybugs, and stresses the importance of developing a pest management plan for vectors of grapevine leafroll disease.

\section{References}

Akbas, B., Kunter, B., \& Ilhan, D. (2007). Occurrence and distribution of Grapevine leafroll associated viruses 1, 2, 3 and 7 in Turkey. Journal of Phytopathology, 155, 122124. 
Alkowni, R., Rowhani, A., Daubert, S., \& Golino, D. (2004). Partial characterization of a new Ampelovirus associated with grapevine leafroll disease. Journal of Plant Pathology, $86,123-133$.

Belli, G., Fortusini, A., Casati, P., Belli, L., Bianco, P. A., \& Prati, S. (1994). Transmission of a grapevine leafroll associated closterovirus by the scale insect Pulvinaria vitis L. Rivista di Patologia Vegetale, 4, 105-108.

Cabaleiro, C., \& Segura, A. (1997). Some characteristics of the transmission of Grapevine leafroll associated virus 3 by Planococcus citri Risso. European Journal of Plant Pathology, 103, 373-378.

Cabaleiro, C., Segura, A., \& García-Berrios, J. J. (1999). Effects of Grapevine leafrollassociated virus 3 on the physiology and must of Vitis vinifera L. cv. Albariño following contamination in the field. American Journal of Enology and Viticulture, 50, 40-44.

Cid, M., Pereira, S., Cabaleiro, C., Faoro, F., \& Segura, A. (2007). Presence of Grapevine leafroll-associated virus 3 in primary salivary glands of the mealybug vector Planococcus citri suggests a circulative transmission mechanism. European Journal of Plant Pathology, 118, 23-30.

Credi, R., \& Babini, A. R. (1997). Effects of virus and virus-like infections on growth, yield, and fruit quality of Albana and Trebbiano Romagnolo grapevines. American Journal of Enology and Viticulture, 48, 7-12.

Engelbrecht, D. J., \& Kasdorf, G. G. F. (1990). Transmission of grapevine leafroll disease and associated closteroviruses by the vine mealybug, Planococcus ficus. Phytophylactica, 22, 341-346.

Goheen, A. C., \& Cook, J. A. (1959). Leafroll (red-leaf or rougeau) and its effects on vine growth, fruit quality, and yields. American Journal of Enology and Viticulture, 10, $173-181$.

Golino, D. A., Sim, S. T., Gill, R., \& Rowhani, A. (2002). California mealybugs can spread grapevine leafroll disease. California Agriculture, 56, 196-201.

Krake, L. R., Steele Scott, N., Rezaian, M. A., \& Taylor, R. H. (1999). Graft-transmitted diseases of grapevines. Australia: CSIRO.

Krüger, K., Saccaggi, D., \& Douglas, N. (2006). Grapevine leafroll-associated virus 3vector interactions: transmission by the mealybugs Planococcus ficus and Pseudococcus longispinus (Hemiptera: Pseudococcidae). Extended abstracts, 15th Meeting International 
Council for the Study of Virus and Virus-like Diseases of the Grapevine, 2006.

Stellenbosch, South Africa, pp 130-131.

La Notte, P., Minafra, A., \& Saldarelli, P. (1997). A spot-PCR technique for the detection of phloem-limited grapevine viruses. Journal of Virological Methods, 66, 103-108.

Ling, K. -S., Zhu, H. -Y., Petrovic, N., \& Gonsalves, D. (2001). Comparative effectiveness of ELISA and RT-PCR for detecting Grapevine leafroll-associated closeterovirus-3 in field samples. American Journal of Enology and Viticulture, 52, 2127.

Martelli, G. P. (1986). Virus and virus-like diseases of the grapevine in the Mediterranean area. FAO Plant Protection Bulletin, 34, 25-42.

Martelli, G. P., Agranovsky, A. A., Bar-Joseph, M., Boscia, D., Candresse, T., Coutts, R. H. A., Dolja, V. V., Falk, B. W., Gonsalves, D., Jelkmann, W., Karasev, A. V., Minafra, A., Namba, S., Vetten, H. J., Wisler, G. C., \& Yoshikawa, N. (2002). The family Closteroviridae revised. Archives of Virology, 147, 2039-2044.

Martin, R. R., Eastwell, K. C., Wagner, A., Lamprecht, S., \& Tzanetakis, I. E. (2005). Survey for viruses of grapevine in Oregon and Washington. Plant Disease, 89, 763-766.

Petersen, C. L., \& Charles, J. G. (1997). Transmission of Grapevine leafroll-associated closteroviruses by Pseudococcus longispinus and P. calceolariae. Plant Pathology, 46, 509-515.

Pietersen, G. (2006). Spatio-temporal distribution dynamics of grapevine leafroll disease in Western Cape vineyards. Extended abstracts, 15th Meeting International Council for the Study of Virus and Virus-like Diseases of the Grapevine, 2006. Stellenbosch, South Africa, pp 126-127.

Roivainen, O. (1976). Transmission of Cocoa viruses by mealybugs (Homoptera: Pseudococcidae). Journal of the Scientific Agricultural Society of Finland, 48, 203-304.

Saccaggi, D. L., Krüger, K., \& Pietersen, G. (2008). A multiplex PCR assay for the simultaneous identification of three mealybug species (Hemiptera: Pseudococcidae). Bulletin of Entomological Research, 98, 27-33.

Sether, D. M., Ullman, D. E., \& Hu, J. S. (1998). Transmission of Pineapple mealybug wilt-associated virus by two species of mealybug (Dysmicoccus spp.). Phytopathology, $88,1224-1230$. 
Sforza, R., Boudon-Padieu, E., \& Greif, C. (2003). New mealybug species vectoring Grapevine leafroll-associated viruses-1 and -3 (GLRaV-1 and -3). European Journal of Plant Pathology, 109, 975-981.

Sokal, R. R., \& Rohlf, F. J. (1995). Biometry (3rd ed.). New York: Freeman.

Tanne, E., Ben-Dov, Y., \& Raccah, B. (1989). Transmission of closterolike particles associated with grapevine leafroll by mealybugs (Pseudococcidae) in Israel. Proceedings of the 9th Meeting of ICVG, Kiryat Anavim, Israel, September 1987, pp 71-73.

Walton, V. M., \& Pringle, K. L. (2004). A survey of mealybugs and associated natural enemies in vineyards in the Western Cape Province, South Africa. South African Journal of Enology and Viticulture, 25, 23-25. 